University of Massachusetts Amherst

ScholarWorks@UMass Amherst

Masters Theses 1911 - February 2014

1917

\title{
The decomposition of organic matter in soils
}

Fred G. Merkle

University of Massachusetts Amherst

Follow this and additional works at: https://scholarworks.umass.edu/theses

Merkle, Fred G., "The decomposition of organic matter in soils" (1917). Masters Theses 1911 - February 2014. 1235.

Retrieved from https://scholarworks.umass.edu/theses/1235

This thesis is brought to you for free and open access by ScholarWorks@UMass Amherst. It has been accepted for inclusion in Masters Theses 1911 - February 2014 by an authorized administrator of ScholarWorks@UMass Amherst. For more information, please contact scholarworks@library.umass.edu. 
THE DECOMPOSITION OF ORGANIC MATTHR IN SOILS

by

Fred G. Herkle

"Thegis submitted for the degree of M. Sc."

Massachusett. Agricultural College

Amherst

June 1917 


$$
\begin{aligned}
& \frac{\text { LIBRARY }}{\text { UNWE STY F }} \\
& \text { MASSAOWUSETIS } \\
& \text { ANHERST, MASS. }
\end{aligned}
$$


occurrence of Carioun Compounds.

Carbon compound are univarsaly distributed in a,11 agrioultural Boils. They are ever being produced and consumed in the natural cycle of the element. The sources of gain in relation to soils are:

$$
\begin{aligned}
& \text { 2. By bacteria } \\
& \text { 2. By green plants } \\
& \text { 3. 3y rains and snows } \\
& \text { 4. Absorption of the gras } \\
& \text { 5. Carbon dioxide from below. }
\end{aligned}
$$

1. Bacteria are usualiy regarded as 1 iberator rather than fixer of the element carbon, yet species have been isolated which perform the latter function. Kamerer(1) demonstrated the production of or ganc matter by bacteria growing in inorganic media in an atmosphere containing carbon and hydrogen. The work twas confirmed by Naboiksh and Lebendeff(?) who showe the diampearence of hydrogen and carbon accompanying their fixation.

2. It is generaliy, not undrersaliy, essuned that green plants take ald their carbon from the aix. Thus green crop plowed under will add 300 to 1,000 polnds of organic matter pex acre (ary basia) or appoximately .04 per cent. Green plant axe, undoubtedly, the greatest source of gain. yet the mount is small in relation to that already existing in the soil. Even yoor soils may contein 60,000 pounds pex acre.

(1) Kaverer, Cent. Makt. 2 abt. 15 (2905) p. 573 ibid. abt. $16(1906)$ p. 681

(2) Nabokish and Lebenderf, ibid. abt. 17 (i906) p. 350. 


\section{Digitized by the Internet Archive in 2013}


3. Rains and snows wash $\mathrm{CO}_{2}$ from the air, probably combined with $\mathrm{NH}_{3}$ as ammonium carbonate. Schumacher(3) gives the $\mathrm{CO}_{2}$ content of rain water as 0.3 to 1.0 volume in 1.000 of rain. Thus, a region having a 36 inch rainfall would annually receive from 400 to 1500 cubic feet of $\mathrm{CO}_{2}$ or from 50 to 175 pounds of $\mathrm{CO}_{2}$. Such a figure seems very small. yet it helps to compensate the numerous loses.

4. Soils have an absorptive power for gases, especially carbon dioxide and ammonia. Ferric hydrate, alunina hydrate, humus and clay appear to be the most active soil constituents as regards absorption of $\mathrm{CO}_{2}$. Reichardt and Blumtritt(4) determined the volume of gas absorbed by equal volumes of various substances and the per cent of $\mathrm{CO}_{2}$ contained. ABSORPTION OF $\mathrm{CO}_{2}$ - REICHARDT AND BLUMTRITT

\begin{tabular}{|c|c|c|}
\hline MATERIAI & $\begin{array}{l}\text { Total gas absorbed } \\
\text { by } 1,000 \text { grams }\end{array}$ & $\begin{array}{l}\text { Per cent } \mathrm{CO}_{2} \\
\text { by volume }\end{array}$ \\
\hline 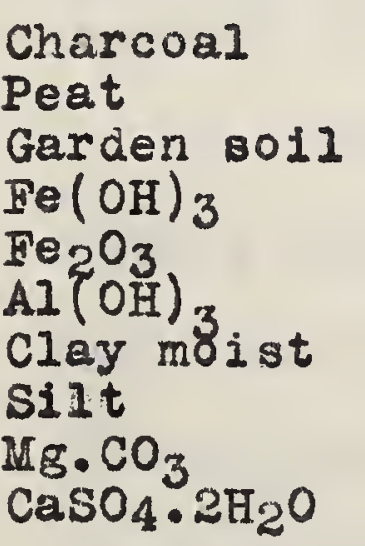 & $\begin{array}{r}164 \\
102 \\
14 \\
375 \\
39 \\
69 \\
29 \\
40 \\
729 \\
17\end{array}$ & $\begin{array}{r}0 \\
51 \\
33 \\
70 \\
4 \\
59 \\
34 \\
32 \\
29 \\
0\end{array}$ \\
\hline
\end{tabular}

The constituents found abundant in clay, viz. - iron and alumina as hydrates, show a strong absorptive power for $\mathrm{CO}_{Z}$. Peat is relatively high. Von Dobeneck(5) obtained the following results:

(3) Schumacher, Ernahrung der Pflanze, Berlin (1864) p. 76

(4) Reichardt and Blumtritt, Jour. prakt. chem.98 (1866) p. 476

(5) Von Dobeneck, Forsch. Agr. Phys. Band 15 (1892) p. 201. 

Quartz 200 grans

Ka02in 200 grams

Humus 100 grams

Fe(OH) 3 100 grains
$0.023 \mathrm{Br} \cdot \mathrm{CO}_{2}$

0.261 .82 .602

1.773 $\mathrm{gr} . \mathrm{CO}_{2}^{2}$

$5.054 \mathrm{~g}^{\circ}: 002$

If we let quartz represent sand and kaolin clay and combine the results of Reichardt and Blumtritt with those of Von Dobeneck it is safe to conclude that the soid'B absorptive capacity for $\mathrm{CO}_{2}$ is largely due to its clay and humus content and to the state of its iron compounda.

To show that soils do actualyy take on carbon by absorption the results of Lemmerman(6) may be cited. Ho allowed a kilogram of soil to incubate for a period of eight weeks. The total carbon was determined at the beginning and end of thig period and an increase of 0.33 grams was observed in one instance and 0.02 grams in another.

5. Many carbon containing deposits exist within the earth's crust. Just how much carbon may come to the aurface from these deposits cannot be determined, but it is probable that methane produced below may gradually sise to the surface and upon reaching better aerated conditions be oxidized to $\mathrm{CO}_{2}$. The deeper soil layers contain greater quantities of $\mathrm{CO}_{2}$ than the surface layers. Fbermayer( $(\eta)$ give the following figures at 70 and $15 \mathrm{~cm}$. respectively.

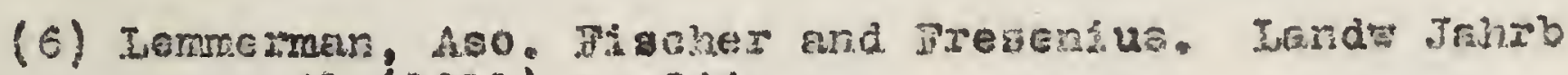
41 (1911) p. 244

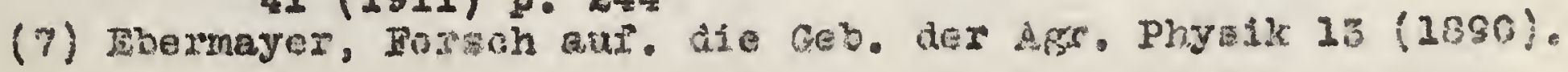



Beech woods

Pine woods

Moss

Sod

Bare ground
$70 \mathrm{~cm}$.

$15 \mathrm{~cm}$.

$70 \mathrm{~cm}$.

$15 \mathrm{~cm}$.

$70 \mathrm{~cm}$.

$15 \mathrm{~cm}$.

$70 \mathrm{~cm}$.

$15 \mathrm{crn}$.

$70 \mathrm{~cm}$.

$15 \mathrm{~cm}$.
$1.19 \% \mathrm{CO}_{2}$
$.62 \%{ }^{11}$

$9.39 " 1 "$
$1.13 " 1 "$

$7.98 " 1 "$

$1.93 "$ "

$7.02 " 1 "$

Pfeffer(8) gives the $\mathrm{CO}_{2}$ content of the soil air at a depth of six meters as $8 \%$ or more.

While it is possible that the increased amount of carbon dioxide in the lower layers is due to the downward flow of the ger, it is more probable that it is diffusing up from below, in which case it would be an additive agent.

\section{SOURCES OF IOSS OF CARBON FROM SOIIS}

Soils may lose carbon: (1) through leaching, (2) through evolution of $\mathrm{CO}_{2}$. (3) through possible removal by crops.

That 80 ils under certain conditions decrease in organic content is frequently observed. Walker(9) reports a decrease in humus content on non-rotated fields as follows:

\begin{tabular}{llll}
\hline & \multicolumn{2}{c}{ Per cent humus } & Difference \\
\hline Corn continuous & 1895 & 1905 & \\
Mangels continuous & 3.23 & 2.96 & -0.27 \\
& 3.03 & 2.86 & -0.18 \\
\hline
\end{tabular}

(8) Pfeffer, Physiology of Plants. Ewart, (1899), vol. I p. 171 (9) Walker, Minn. Exp. Station, Tech. Bulletin 128, f. 179 . 

Rotated fields and fields growing legumes continuously showed a slight gain in the ten-year period. Hooers, Hampton and Hunter(10) show that only when the crop is removed can a decrease in humus content be expected.

1. Loss through leaching. Soils have a strong absorptive power for organic matter; therefore, little or no carbon is lost in that form. To show what a small amount of organic matter is soluble in the presence of soil, analynes by Sutton(11) are here quoted. He analyzed the surface water of cultivated fields and found it to contain but .4 part of organic matter in 100,000, seeming insignificant amount. If organic matter were subject to losg by leaching we would expect the subsoil of a continuously manured plot to contain more carbon than that of a non-manured plot. Such is not the case. Dyer(12) shows that the subsoil of a plot manured for fifty years contains no more, even leBs, carbon than that of a plot undunged for forty-one yeara.

Carbon in third

Dyer

9 inch layer of soll

Dunged 9 years, uncunged 41 years Dunged 50 years
$.515 \% \mathrm{C}$ $.492 \%$ C

The difference is within the limit of error.

To be capable of leaching organic matter must be $801-$ wble and when in solution it is easily precipitated by baser. Carbon as bi-carbonate of lime is easily lost as is shown by frequent analyses of drainage waters fxom limed

(10) Mooers, Hampton and Hunter, Tenn. Exp. Station Bulletin 96, part II

(11) Sutton, Volumetric Analyaia, Eth Ed. (1900) p. 496

(12) Dyer, Office of Exp. Stations Bulletin 106, s. 39. 


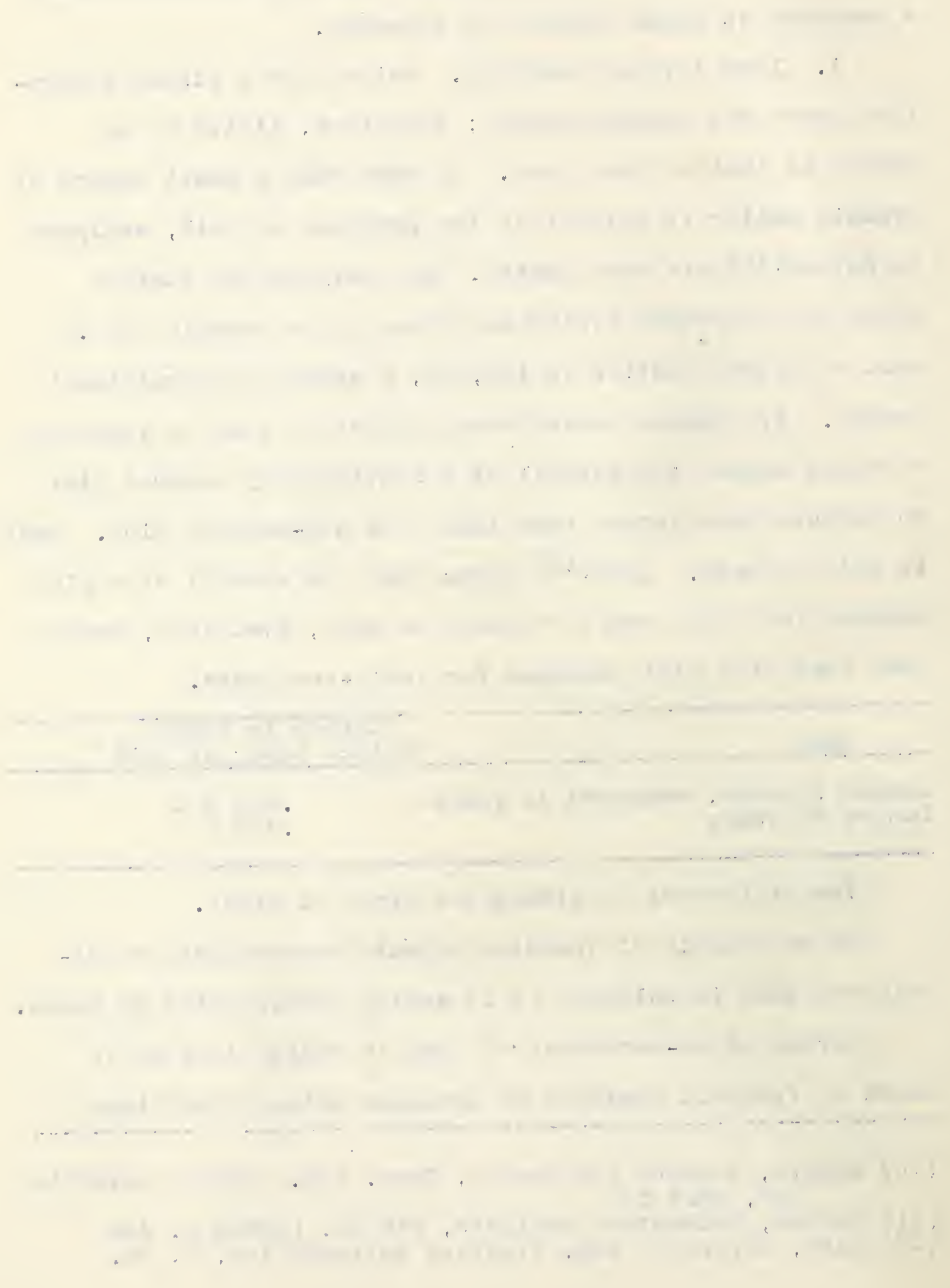


Lielda $\{3\}$.

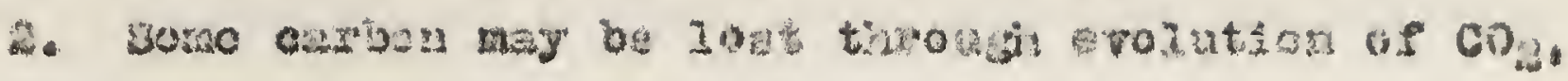
but if any the amount yast be sidgit.

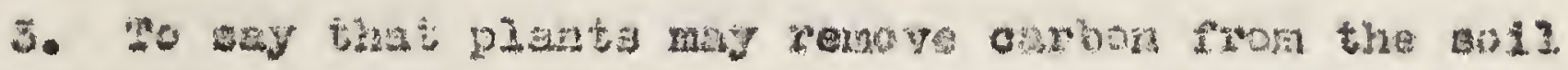

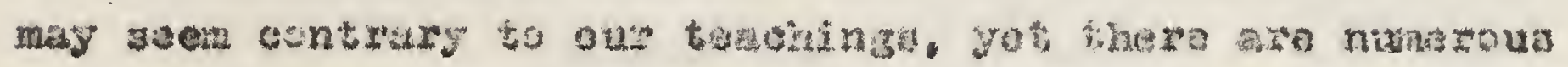

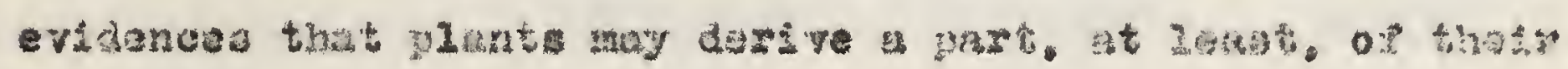
carbon though whest roots.

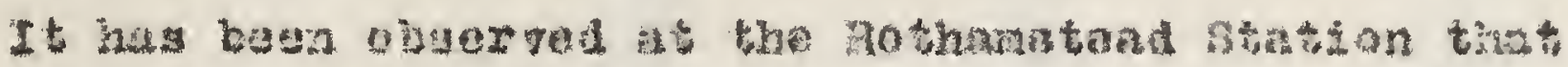

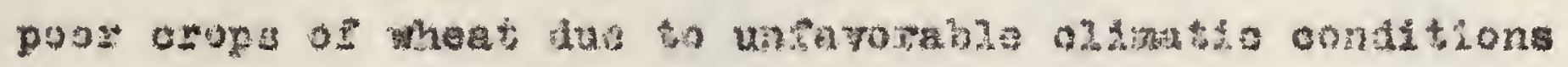

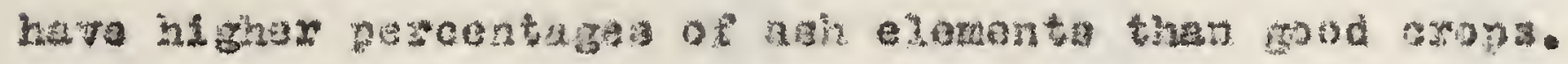

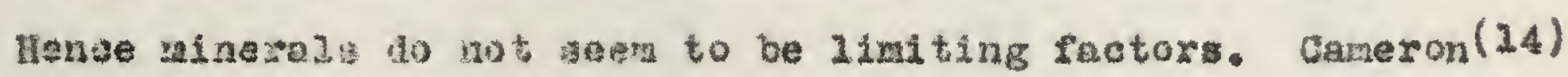
uses this argunent to prove that the use of mineral fertiliaers

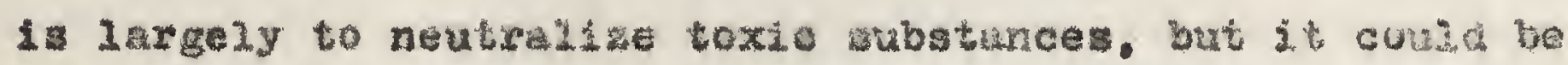
used equaliy well to ghow that the ayntheadic of organce nattex, as weIl as the assimulation of minezals is an iraportant frotor in plant growth.

To show the value of organd mater in aqueous extracts of poor goils the Bureau of Soilg(25) used a manure extract as follows: One portion of the extract was evaporated and ignited to destroy the organic nater. The other part was used without sgnition. The solution to which the unignited manure extract was added gave far superior growth. Canexon attributes the value of the organic matter in the extract to Its probable absorbent action on toxic substances, but it is al go probable that the plant absorbed certain organic nutrients from it.

(13) Ha11 and laler. \$roc. Ruy. Soc. sez 7r (1005) p. I (14) Camoron. The soll solution (1911) D. 14

(15) 2 bid. p. 85 . 

Gardner(16) determined the effect of many substances, mineral and organic, on transpiration and upon the amount of green matter produced per unit of water transpired. The following figures give the summarized results of many trials:

\begin{tabular}{lccc}
\hline & $\begin{array}{c}\text { Growth due } \\
\text { fertilizer }\end{array}$ & $\begin{array}{c}\text { Growth per } \\
\text { unit water } \\
\text { transpired }\end{array}$ & $\begin{array}{c}\text { Transpiretion } \\
\text { per unit } \\
\text { grovth }\end{array}$ \\
\hline check & 100 & 100 & 100 \\
P & 104 & 103 & 97.0 \\
K & 113 & 107 & 93.6 \\
K.P. & 118 & 108 & 92.6 \\
Iime & 127 & 103 & 97.0 \\
N.P. & 145 & 116 & 86.2 \\
N.P.K. & 144 & 119 & 84.0 \\
N.K. & 152 & 123 & 81.3 \\
N.P.K.I. & 154 & 125 & 80.0 \\
Hanure & 173 & 129 & 77.5 \\
Clover and lime & 193 & 135 & 74.0 \\
& 197 & 143 & 69.9 \\
\hline
\end{tabular}

It will be noted that the last two treatrents, which are organic, not only gave the greatest growth, but gave the greatest growth per unit of water transpired. This work was done with soil solutions so the effects of the organic matter cannot be due to its action on the physical condition of the soil, nor to its solvent action upon minerals. It is fair to conclude that the presence of carbon in the soil solution decreasea the transpiration necessary to produce a unit of dry matter, a strong indication that plants may assimilate carbon through their roots. Quarrie(17) reports large increases in garden crops through the application of carbon dioxide to the soil through

(16) Gardner, Bureau of Soils, U.S.D.A. Bulletin 48, P. 54 (17) quarrie, The Application of $\mathrm{CO}_{2}$ gas to the SoiI; Scientific American, Supplement (1914) p. 399. 


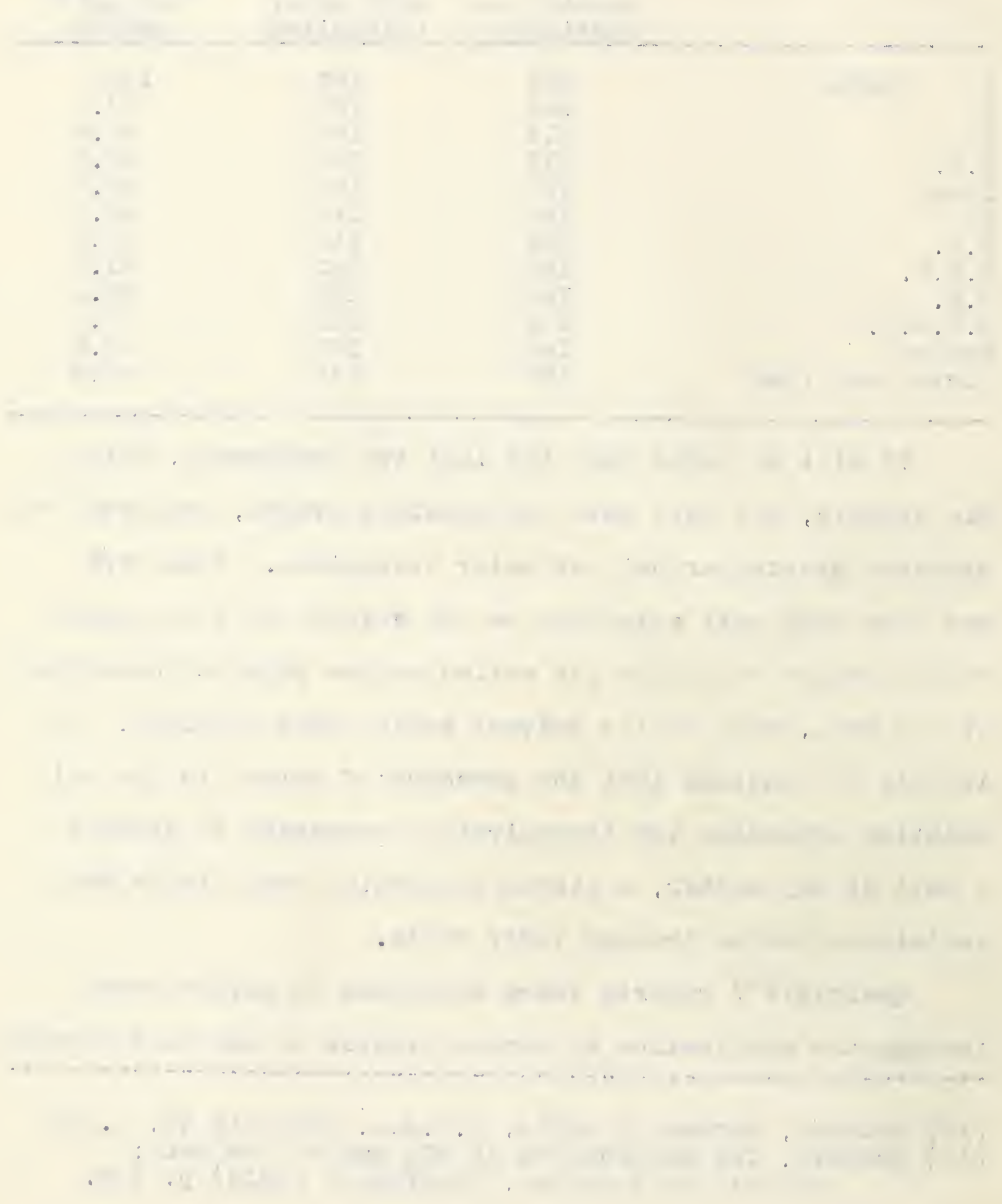


pipes. Bornemann(18) reports like results with spinach. Mitscherlich(19), on the other hand, obtained no increase from the application of water saturated with $\mathrm{CO}_{2}$. The possibility of adding an excess of water or of gas renders the results inconclusive. We know that in ordinary practice $\mathrm{CO}_{2}$ producing materials are seldom injurious. Desassure $(20)$ compared the growth of plunte in pure water with water containing one-fourth its volume of carbon dioxide and found that the carbonated water was injurious to growth in the early atages, but not so later in the life of the plant. At the conclusion of the experiment the plants grown in the carbonated water weighed 46.4 grams, while those growing in pure water weighed 45.5 grams.

Hellreigel and Wilfarth(21), Franke(22), Berthelot(23), and Schoegsing and Laurent (24) all report the utilization of organic nitrogen by green planta. Schreiner(25) and his associates have isolated createnine, an organic nitrogen compound, from soils and proved ita beneficial action upon plant growth.

(18) Bornemann, D.I.G. 28 (1913) No. 31, p. 443

(19) Mitscherlich, F.A., Iandw Jahrb, Bd 39 (1910) p., 157-166

(20) DeSassure, Theod. Recherches Chemiques sur la Végétation. Paris $1804,1.27$ and 28

(2l) Hellreigel and Wilfarth, Ann. Agron. Tome XV

(22) Franke, Ann. de la Soc. Agron. Tome II

23) Berthelot, Ann. de Chim et de Phys. Tome XIII, P. 5

24) Schloessing and laurent, Ann, de linstitute Pasteur Tome VI

(25) Schreiner, Shorey, Sullivan and skinner, U.S.D.A. Bureau of Soils Bulletin 83. 

Lef'evre(26) grew planta in an artificial soil made from sand and moss, supplied with amids and sterilized so that further oxidation of these compounds would be avoided. The entire plant was enclosed in an atmosphere freed from carbon dioxide. Unaer such conditions it is evident that any growth must result from the assimilation of the amids. Leferve obtained normal growth and concludes that: 1. In a soil supplied with amids one may develop green plants without carbon dioxide. 2. (27) The growth thus produced is a real synthesis not a (pouséé aqueuse). 3. (28) Without light synt'lesis from amids is impossible.

so much for nitxogenous organic substances. Molliard(29), using glucose, end laurent (30) end Knudson(31), using other carbohydrateo have shown that plants assimilate sugars and that these sugars are used to synthesize dry matter. Ravin(32) compared the effects of organic acida with their acid and neutral salts and concluded that such organic

(26) Lefévre. Jules, Sur le developpement des plantes vertes a Ia lumiere en l'absence complete de gas carbonique dans un sol artificial des amides. Comptes. Rendus. 141 (1905) p. 211-213, also p. 664-665

(27) Ibj.d., p. $834-835$

(2.8) Ibid., p. 1035-1036

(29) Molliard, M., Culture pure des plantes vertes dans une atmosphere confineé en présence des matiéres organiques. Comptes. Rendus.141 (1905) p. 389-391

(30) Laurent, M.J.. Recherches sur la Nutrition Carbonée des Pluntes Vertes a I'aide de Matiérea Organiques. Revue General de Botanique, Tome 16 (1904) p. 14-43

(31) Knudson, Lewis, Influence of certain Carbohydrates on Green Planti. Cornell Memoir 9 (1916)

(32) Ravin, Nutrition Carboné des Phanerogames a I'aide de quelques acids organiques et de leur sels potassiques. Comptes. Renaus. 154 (1912) p. 1100-1103. 

acido as malic, tartaric, citric, succinic and oxalic may be assimilated by plants and further that these organic acids are more nutritive than their corresponding salts or acid salts.

So far we have considered the assimilation of carbon from materials of known composition; namely, $\mathrm{CO}_{2}$, amids, carbohydrates and organic acias. Molliard(33), to put the matter on a more practical basis, experimented with humus extracted from soil. The work was carried on under aterile conditions, but it was impossible to prevent, entirely, the evolution of $\mathrm{CO}_{2}$; therefore, definite conclusions cannot be drawn.

The most conclusive proof that green plants can take up carbon compounds through their roots is their growth with the foliage enclosed in an atmosphere entirely devold of carbon dioxicie. Pollacii(34) grew plants in a culture bottle within a large receptacle, each being provided with tubes so that the water or air in each may be renewed and controlled independently of the other. The plants were sealed into the stopper with wax. By adding $\mathrm{CO}_{2}$ to the nutrient solution and excluding it from the aerial portions of the plant he has successfully grown plants and even revived the chlorophyl in etiolated leaver.

(33) Holliard, M., I'humus est il un source direct de Carbon pour plantes vertes superiense? Comptes. Rendus. 154 (1912) P. 291-294

(34) Pollacii, G., Nuove Recherche Sull'assimilazione Del Carbonio. Bullitinino Della Societa Botanica Italiana (1911 and 1912) p. 208-211. 

From the evidence in the foregoing pages it may be concluded that green plants can, and probably do, take carbon through their roots. Just what form or what proportion of the total carbon in the plant this may be cannot be stated, but the fact itoelf is enough to make us turn our attention to the soil organic matter. 

DECONPOSITION OF ORGANIC MATIER

Hopking(35) states that: "It is the decay of organic matter and not the mere presence of it that gives life to the soil. Partially decayed peat produces no such effect upon the productive power of the soil as follows the use of farm manures or clover resiaues." Löhnis(36) declares that the organic matter is the life of the soil and upon its decay depends the fertility of the soil.

Realizing the importance of organic matter and its decomposition with reference to soil fertility many investigations, demonstrating the rate of decay and factors influencing it, have been made.

Van Suchteln (37) has used the rate of decay, measured by carbon-dioxide production, a a measure of bacterial activity. This method recognizes $\mathrm{CO}_{2}$ as the ultimate and most representative end product of decay. He showed the influence of moisture and of frost, the effect of soluble sugars and of salts on bacterial activity. His results showing the action of fertilizers on the rate of decay are closely related to our subject and will be reported. He mixed the materials in six $\mathrm{Kg}$. of soil and determined the amount of carbon dioxide produced in twelve hours.

(35) Hopkins, Soll Fertility and Permanent Agriculture (1910) (36) Löhnis, Boden Bakterien and Boden Fruchbarkeit. (37) van Suchteln. Uber die Messung der Lebensthatigkeit der aerobischen Bakterien in Boden durch die Kohlensauer produktion. Cent. Bakt. etc. Abt.2, Bd 28 (1910) p. 45 . 

van Suchteln

Action of Fertilizer Materials

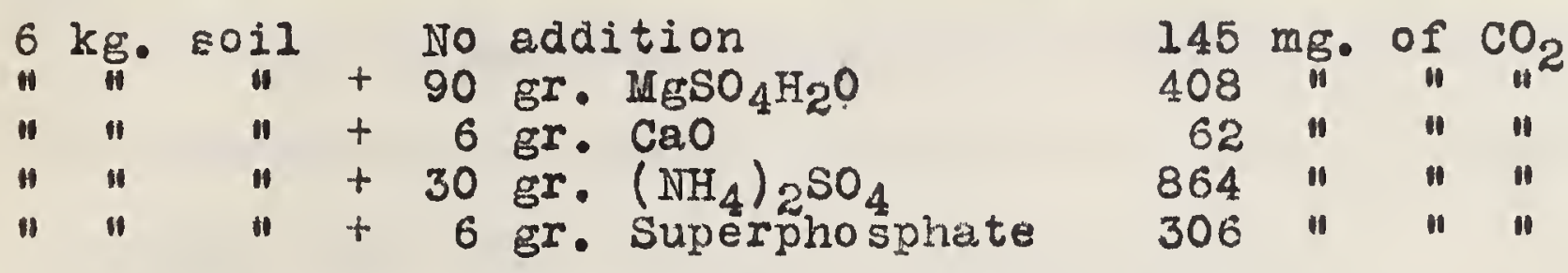

The increases from applied materials are quite large with the exception of lime, which has evidently absorbed the gas produced. One function of fertilizers may be to hasten the decay of organic matter.

Lemmerman $(38)$ and associates worked with the influence of lime compounds on decay. They compared the oxide and carbonate. They found tirat $\mathrm{CO}_{2}-$ production could not be taken as a measure of bacterial action with lime, because the oxide absorbed and the carbonate gave up $\mathrm{CO}_{2}$. To offset the difficulty they carried on balance experiments in which the total carbon was determined before and after the incubation period, which lasted eight weeks. Their experiments show that (1) line hastens decay, (2) kainit and a mixture of kainit and superphosphate does not increase decay, (3) dry organic matter decays as rapidly as the same material fresh. Potter and snyder(39) report some work along this line. In their experiments the soil was placed in pots under bell

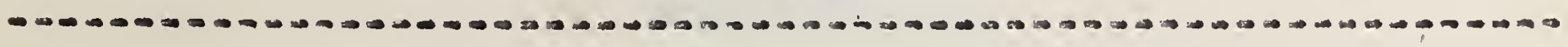

(38) Lemmerman, Aso. Fischer and Fresenius, Untersuchung uber die Zerzetzung der Kohlenstoff verbindugen verscheidener organischer Substanzen im Boden speziell under dem Tinfluss der Kalk. Landw Jahrb. 41 (1911) p. 216-25"

(39) Potter and Snyder, Carbon and Nitrogen Changes in the Soil variously treated with Ammonium Sulphate and Sodium Nitrate. Soil Science Vol. I, No. I (1916) p. 76-94. 

jars and the $\mathrm{CO}_{2}$ evolved was measured by drawing air over, not through, the soll. Their observitions will be mentioned latex. Fred and Ifatito) showed that sulphete of almonia, sulphato of gotan sud ynophates increased the carbon dioxide pro. duction, the first named to a marked degree.

Fussuld (12) meature oxidation by determining the axygen absorbad rather tha the $\mathrm{CO}_{2}$ produced. Fither method shoudd give about the same rasula, for many analyses show that a

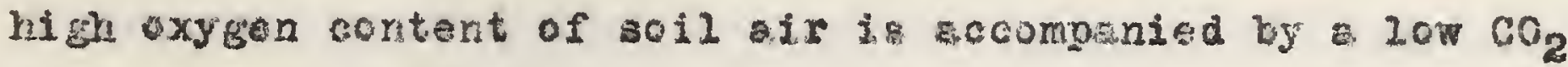
content and vice verma. In other words the sum of the oxygen and carbon doxide is rearly coastant.

Fuskell' metrod is to piace the goil in slak, connected

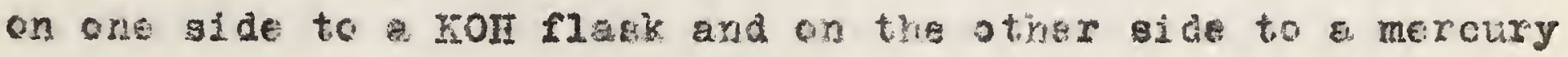
tube. The $\mathrm{KOH}$ aborb any $\mathrm{CO}_{2}$ evolved and the rise of mercury in the other arm indicates the oxyger absorbea.

He determined the oxidation of nany soLis by this method and concluged that (2) in different soils of the same type the rate of oxidation varies in the ame way a the fertidity ard may be uged a measure of it. mhis, if true, is imgortsnt, for we have no other leboratory method of determ minirg the relative fertility of soja.

\section{BXPERIUIFTAI.}

The work of previous inveatigatora indicotes oxidation to ke e mencure of fortility in ecila; hence, the rete of (40) Fred and Fert, Comparative tffect of Phosphates and

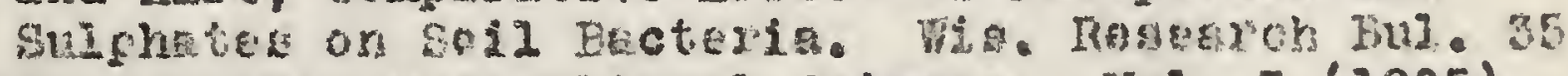
(41) Buscel1, Icurral fsricultural science. Vo1. I (1805) p. $261-279$. 



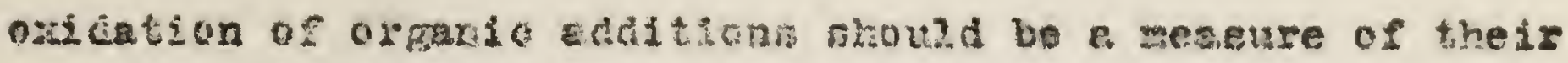

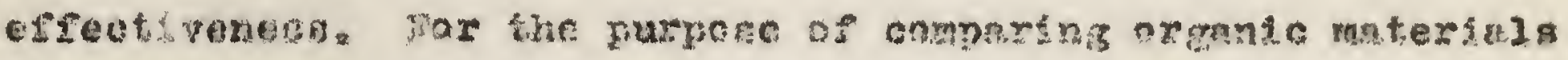

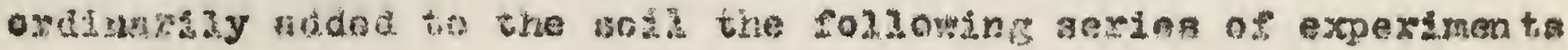

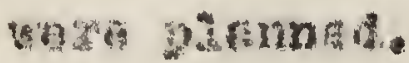

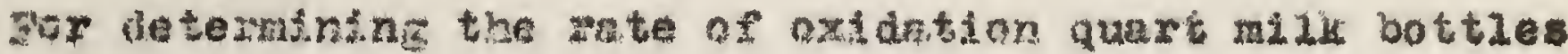

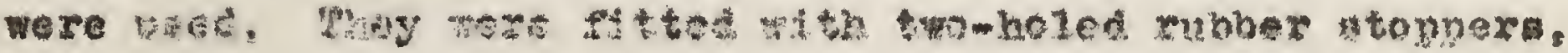

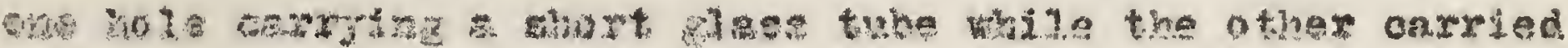

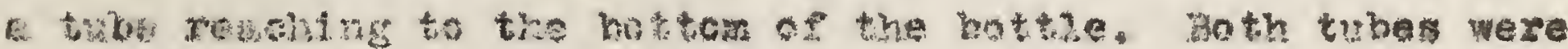

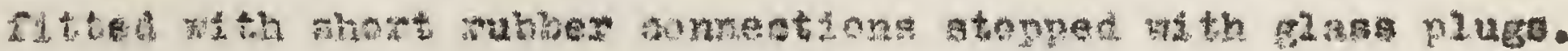
pwo hunder from of meshed tratrel were paced in the bottom

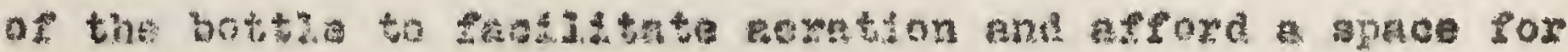

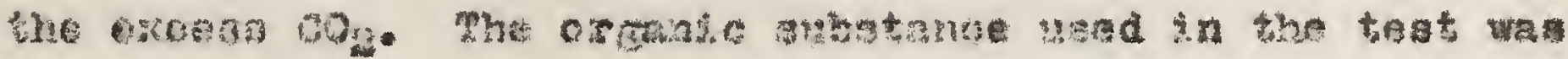

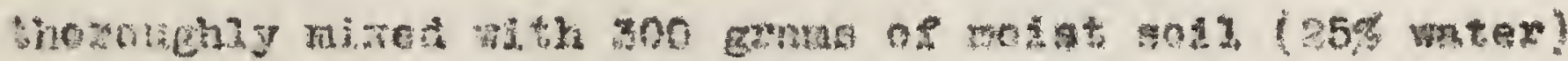

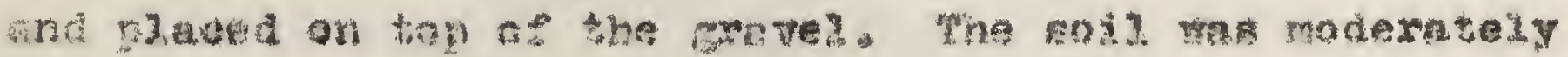
corpocoted by somping.

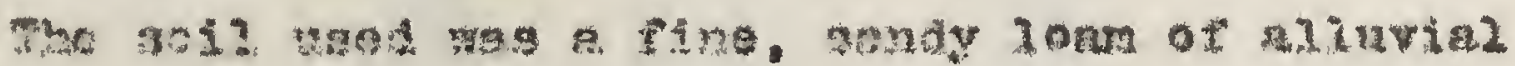

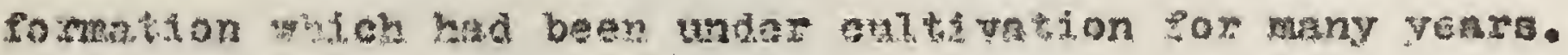

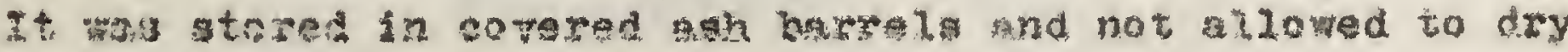

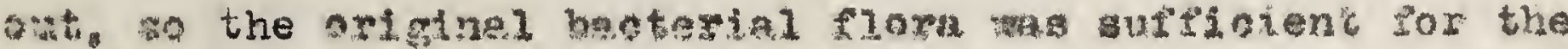

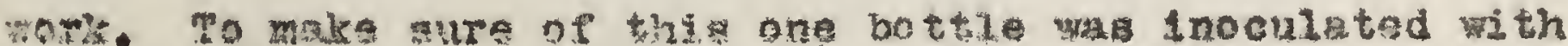
20 co. of a maure syspension. This bottin gave the Brus anount of $\mathrm{dog}_{2}$ as the uninosulated gne netax the first reek of Incubation, showing that there was no defictency of

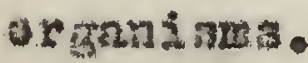

The rate of axidation was determined by measuring tine arount of cog produced ason week os follows. The zubbez connentions were clesed with pinch cooks, the elass piugs removed nnd the bottleg connected with the absorption bottles. 



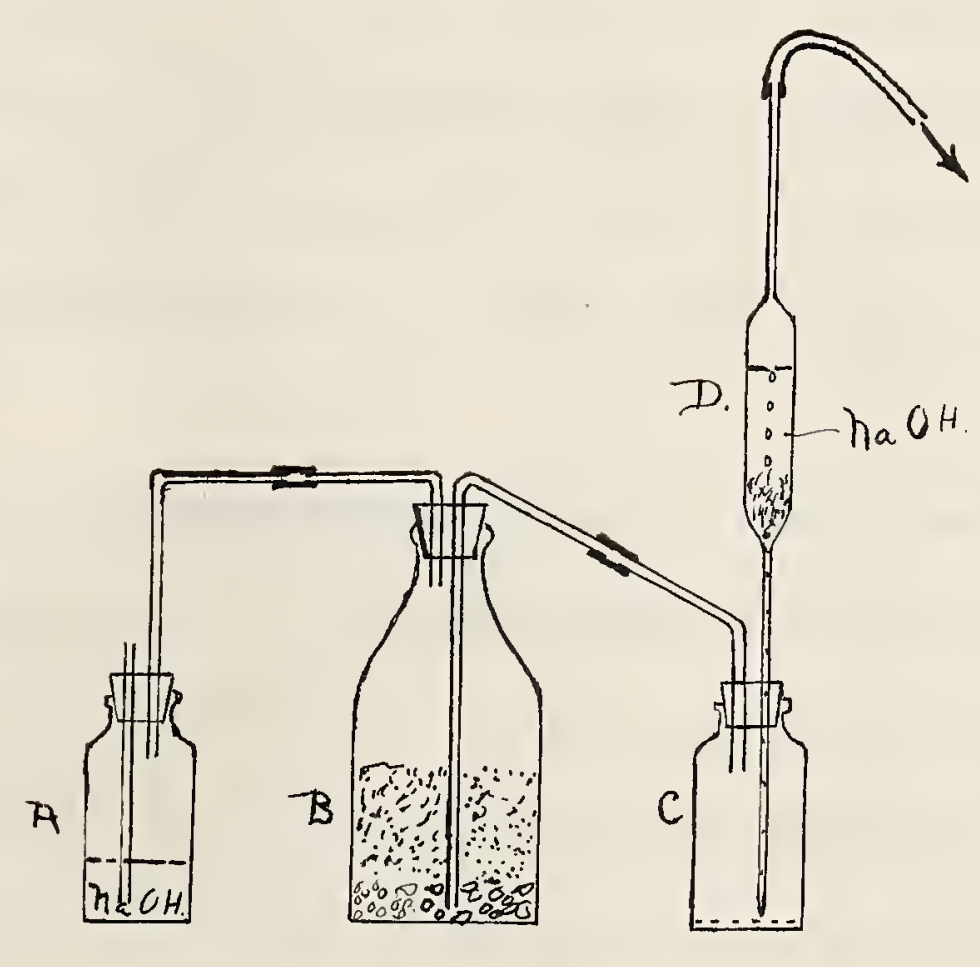



as shown in the diagram. First is an absorption bottle (A) containing NaOH to free the incominis air of $\mathrm{CO}_{2}$. Next is the incubation bottle (B) with its outlet tube reaching the bottom to make sure of complete removal of the $\mathrm{CO}_{2}$ produced. The absorption apparatus (C) was devised to take the place of a Reisset(42) absorption tower. The tower (D) is an ordinary $100 \mathrm{cc}$. pipet filled with broken glass or boads to increase the absorption surface. The pipet is connected with a Chapman filter pump. It was found that axapid stream of air could be drawn through this tower without danger of incomplete absorption, and also that four minutes of strong aspiration was sufficient to remove all $\mathrm{CO}_{2}$ fror the generating fl. $3.8 \mathrm{k}$.

Each bottle was aspirated once a week, using $500 \mathrm{cc}$. of $\frac{\mathrm{N}}{2} \mathrm{NaOH}$ as the absorbent. The $\mathrm{CO}_{2}$ was determined by the double titration method $(43)$. A $20 . \mathrm{cc}$. aliquot of the carbonated soda is titrated with phenolpthalein against HCl, first using normal acid until near the neutral point. Neutralization is completed with $\frac{N}{10}$ acid. This rnarks the conversion of carbonate to bi=carbonate, neutral to phenolnthalein.

$\mathrm{Na}_{2} \mathrm{CO}_{3}+\mathrm{HCl}+$ phenolpthalein $\longrightarrow \mathrm{NaHCO}_{3}+\mathrm{NaCl}$. The amount of acid needed to make this change need not be known, nor is it necessary to know the normality of the alkali used.

(42) Reisset, Compte. Rendu. Vol. 38, p. 1001 and Vol.90, p. 1144

(43) Brown and Escomb, Proc. Roy. Soc. 76 (1905) p. 29. 

Methyl orange is now added and ${ }_{10} \frac{\mathbb{N}}{0} \mathrm{HCl}$ run in drop by drop till the neutral point is reached. The exact amount is recorded and is equivalent to the $\mathrm{CO}_{2}$ contained. $\mathrm{NaHCO}_{3}+\mathrm{HCl}+\mathrm{mo} \longrightarrow \mathrm{NaCl}+\mathrm{H}_{2} \mathrm{O}+\mathrm{CO}_{2} \cdot$ One cubic centimeter of $1 \frac{N}{1} \mathrm{HCl}$ equals 4.4 milligrams of $\mathrm{CO}_{2} \cdot$

Cochineal gives about the same result as methyl orange. but the latter was used throughout this work. 



\section{EXPIRIMENT I}

LEGUHE FODDIRS

The plants were cut off at the surface of the ground when in full bloom or as near that stage as possible. They were aried, slowly at first and later in the oven. When dry they were ground and reground until all the material would pass through a $2 \mathrm{~mm}$. sieve. Fifteen grans were mixed with 300 grams of moist loam, placed in the inoculation bottles on top of a layer of gravel and slightiy compacted. The bottles were stoppered and the olutlet tubes closed with glass plugs. They were allowed to incubate in the dark at room temperature, the $\mathrm{CO}_{2}$ produced being measured weekly (usually) in the manner just described. An untreated soil served as a checis ior all the following experiments.

TABLE I MILLIGRAHS $\mathrm{CO}_{2}$ PRODUCED

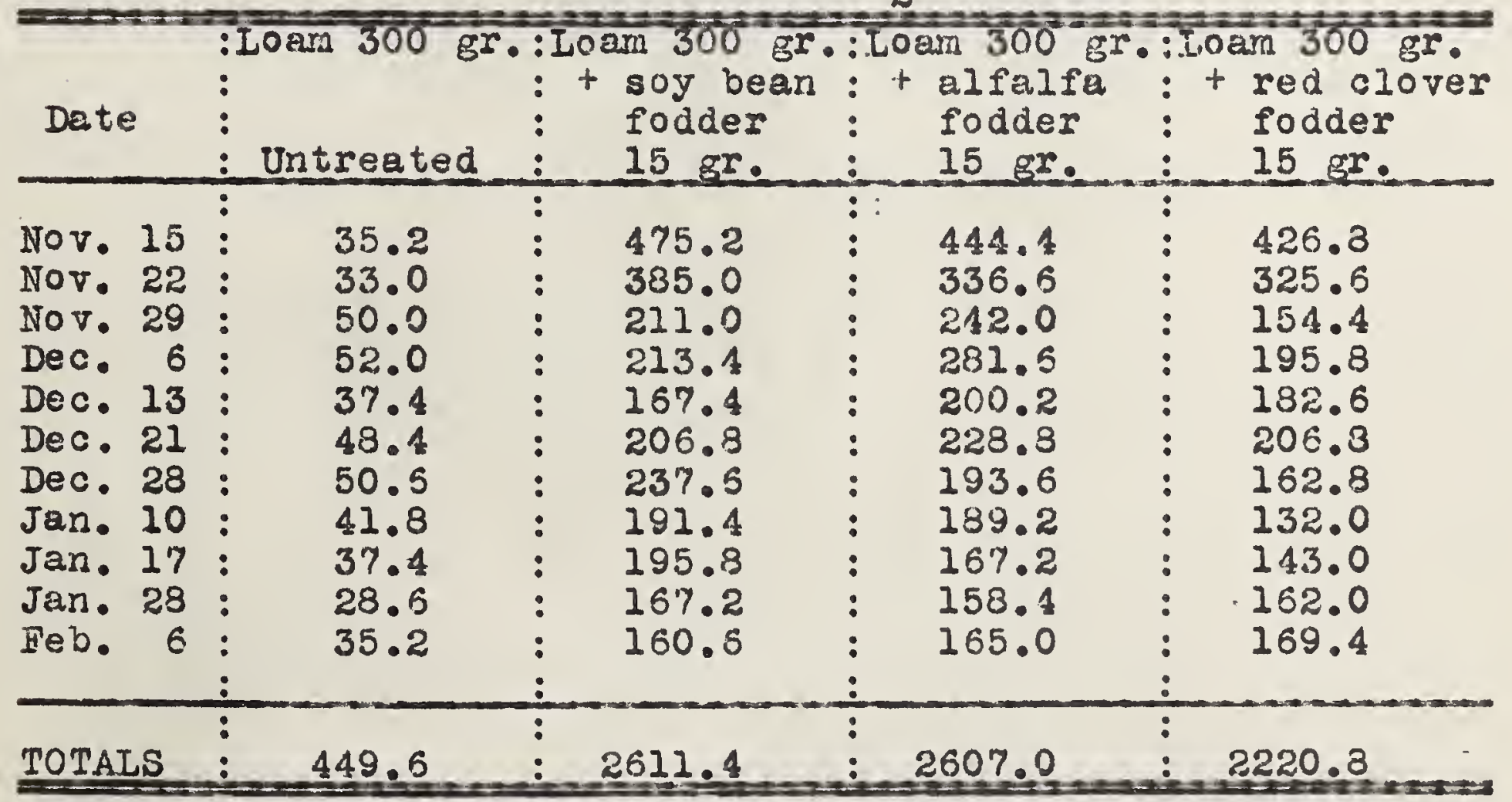





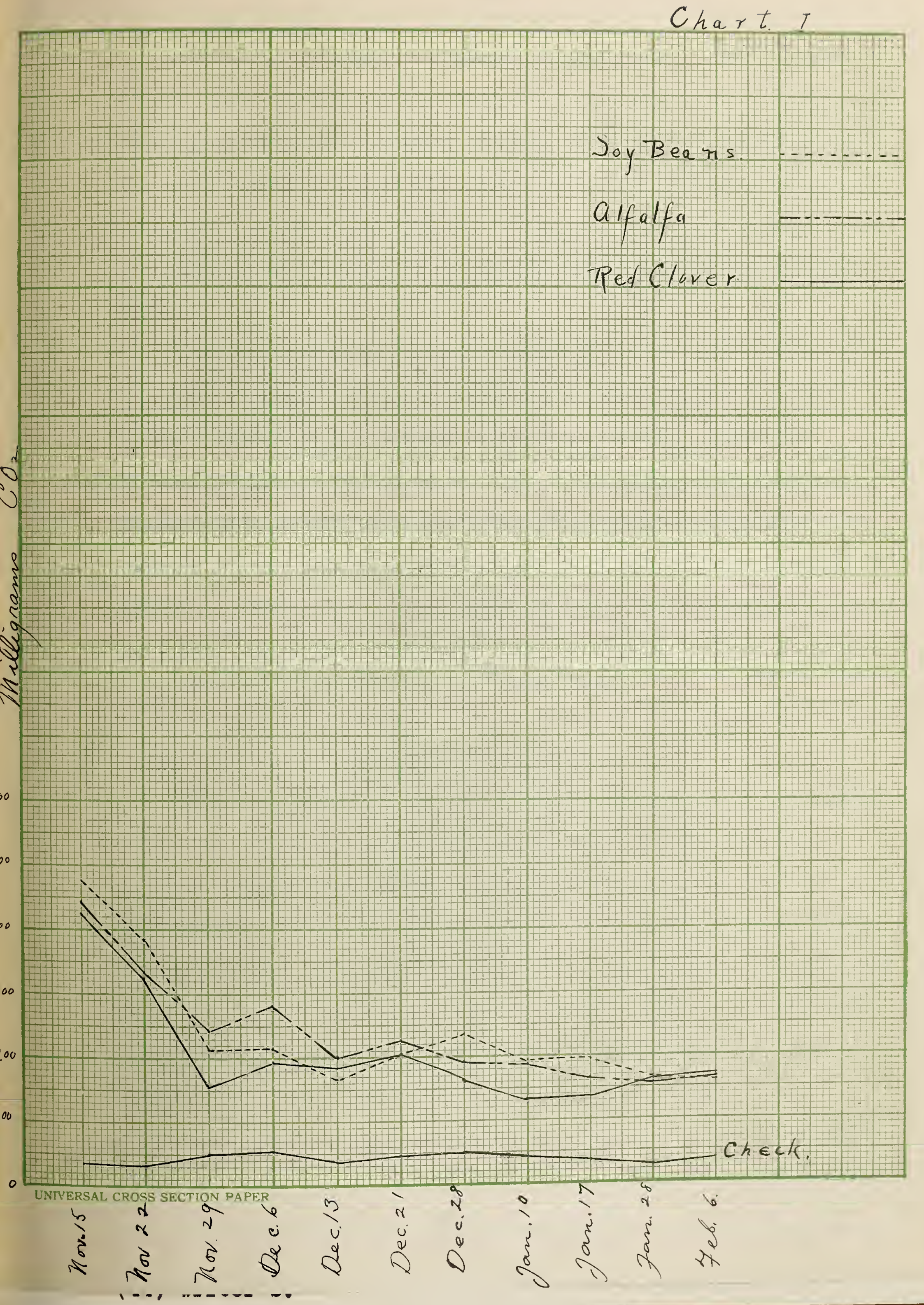



The above figures are plotted in Chart I. They show that a rapid production of $\mathrm{CO}_{2}$ take place the firat two weeks after a legume fodder starts to decay, and that after the second week they settle down to a steady rate of decomposition. Apparently red clover decays a little slower than the other fodders, but there is no great difference between them.

There are possibilities of errors in the aspiration of the gas, but the irregularities in the curves are due to these. Temperature changes affect all alike, hence the general tendency is for all to rise and fall at the sane period, though not always in the same degree. The uniformity of the check indicates the accuracy of the method. Duplicates were run in the early part of the experiment but the close agreement seemed to justify dropping them to save work.

\section{HUIUS PRODUCTION}

Equaliy important as the rate of oxidation is the humus produced. A substance may oxidize very rapidly, as for example sugars, and still not increase the humus content noticeably. Such substances would be of questionable value as regards the physical improvement of the soil. Unpublished mork(44) shows that sugars break up very rapidly in the soil and are nearly completely oxidized within a reek or two. Lactose, maltose, saccarose, dextrose and fructose run about the same. Sugar beets (Chart II) in the early stages of decay show the effect of their sugar, but later gave about the same results as the rape and swedes. 

The materials used in the $\mathrm{CO}_{2}$ production experimerts, having been allowed to incubate from November 8 th to February 19th, were removed, dried and their humus content determined by the official method. The regults are recorded together with the total $\mathrm{CO}_{2}$ production for comparison. PABI, IF II HUMUS PRODUCTION

Hurnue, per cent

$2.96 \%$
$3.43 \%$
$3.29 "$
$3.285 "$

Total $\mathrm{CO}_{2}=\mathrm{Cg}$.

$\begin{array}{rc}44 & \text { Cg. } \\ 260 & \text { " } \\ 220 & " 1 \\ 261 & \text { " }\end{array}$

The figures indicate that there is little choice between the legumes in decay and hurnification.

\section{EXPERIMENT II \\ ROOT CROPS AND RAPE}

These substances were used to compare readily decomposable carbohydrates, as found in plants, with more inert materials. For this purpose sugar beet roota, swede or rutabaga roots and rape tops were used. All of these contain some forra of atored food, sugar or starch. The plants were taken from the field, air dried, then oven dried, and ground fine enough to pass a $2 \mathrm{~mm}$. sieve. Fifteen grans of each wero mixed with 200 grams of moist soil and placed in incubation bottles as previously described.

Determinations of $\mathrm{CO}_{2}$ produced were made weekly. 

TABIE III

MILIIGRAIS $\mathrm{CO}_{2}$ PRODUCED

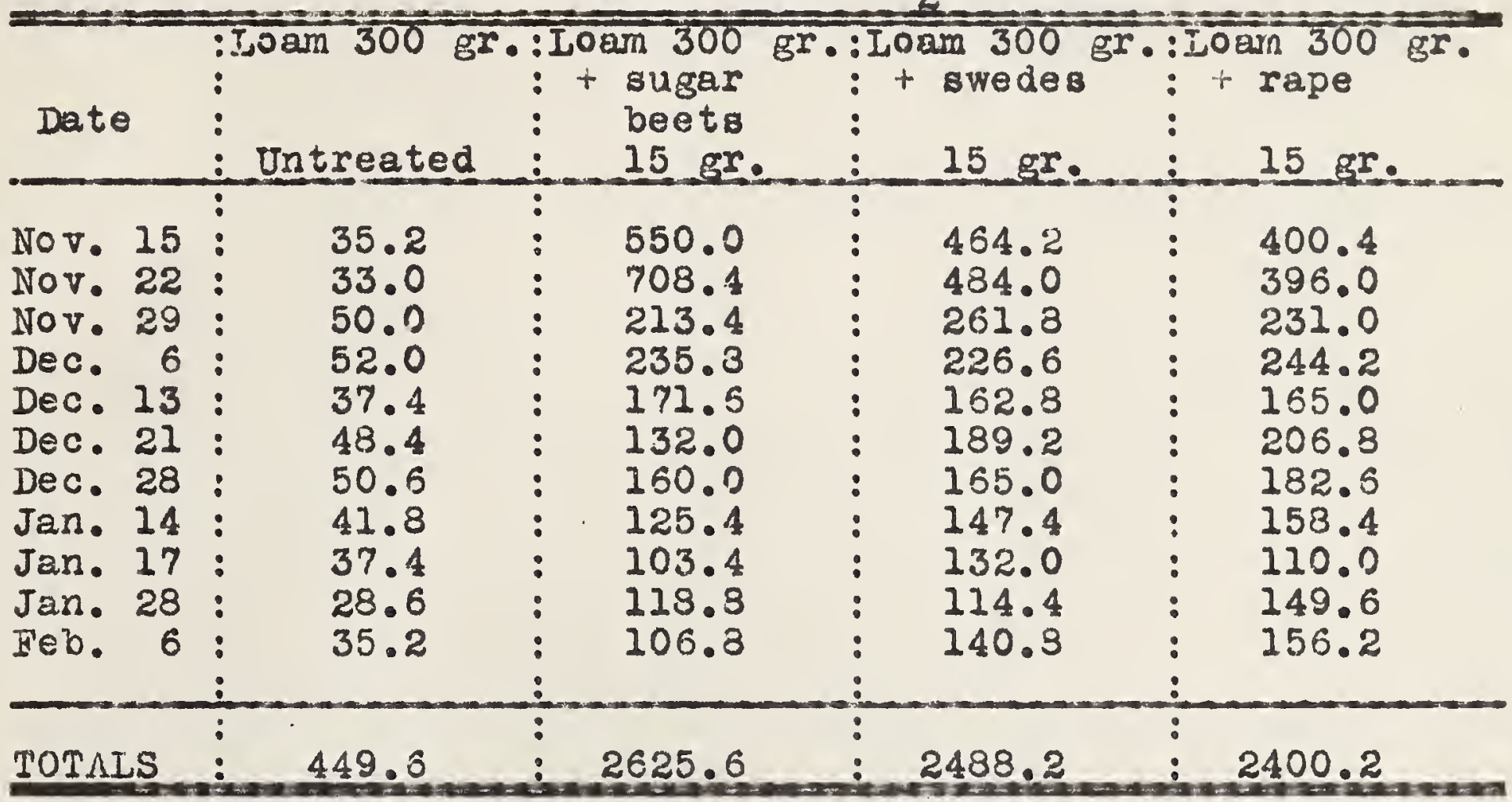

Sugar beets, Chart II, as might be expected, show rapid decay at the start but the sugar is all oxidized in two weeks, after which time the organic matter in them is no more decornposable than that of other materials. Rutabagas contain but little sugar and decay no faster than legume fodders. Rape is slowest at first but as time goes on it exceeds the others. Comparing the legurnes with roots we find that the former are more readily oxidized as time goes on, that is, after the sugar in the rootg is broken down.

\section{HUIUS PRODUCTION}

The results of the humus deterinination are as follows:

TABLE IV

Humus, per cent Total $\mathrm{CO} 2-\mathrm{Cg}_{2}$

So11 No treatment

$2.96 \%$
$3.56 \%$
$3.28 \%$
3.24

44

248

262

" + Sugar beets

" + Rape

3.24

240

$\mathrm{Cg}$

"1

H 


The difference as shown by the humus figures seeing the more representative, since the higher $\mathrm{CO}_{2}$ production for sugar beets is due to the sugar. Rape falls in third place in both instances.

\section{EXPPRIMTENT III}

\section{IITTERS}

The materials listed below find their way into the soil through natural agencies or as litters and were selected with the expectation of obtaining large differences. It was thought that pine needles might even lower the bacterial activity, at least for a time.

Pine needles, oak leaver and maple leaver were picked while still green, air dried and later oven dried. White pine shavings, as used for litter, were oven dried. Each substance was ground and sieved. Fifteen grams were used in each case.

TABLE V MILIIGILAMS $\mathrm{CO}_{2}$ PRODICED

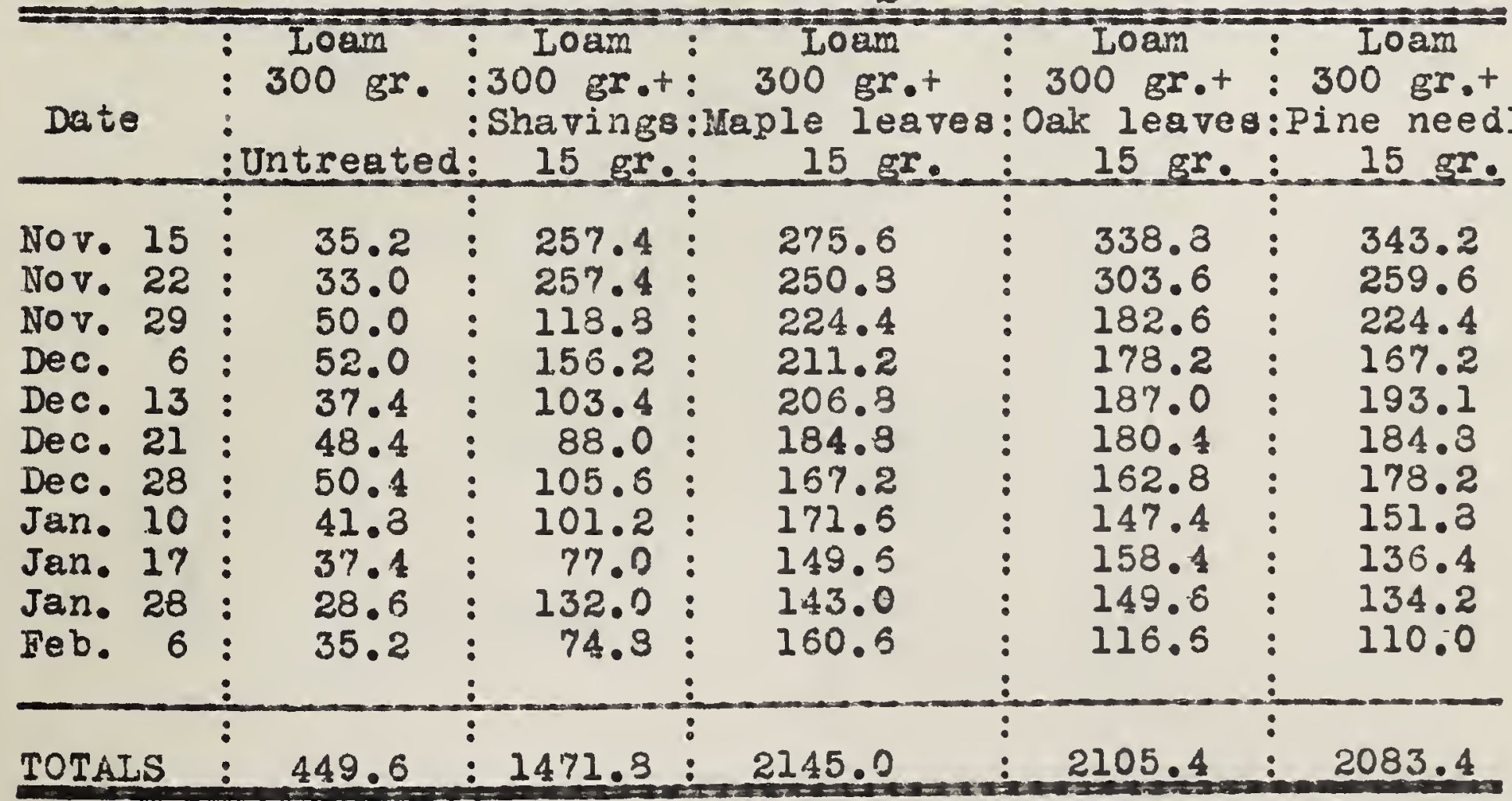





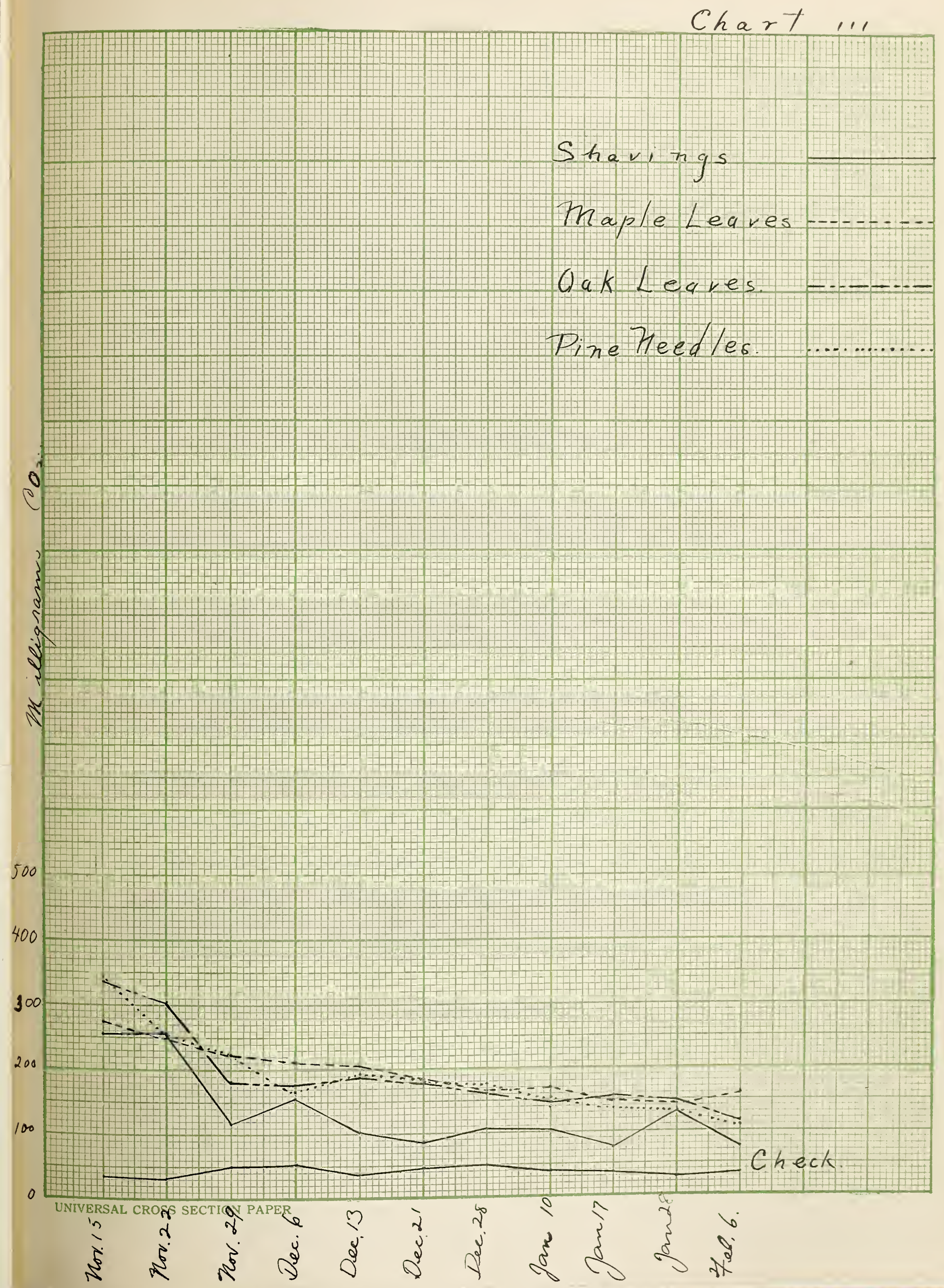



See Chart III.

White pine shavings stand out as a striking example of an inert substance, being lowest and slowest in $\mathrm{CO}_{2}$ production. Maple leave give a more uniform decline than anything else.

The litters in general, as might be expected, are not as rapidiy decomposed as either legumes or root crops and suggest the importance of nitrogen as an aid to oxidation, as those materials which are low in nitrogen are slow to oxidize. This latter statement applies to the later stages of decomposition.

\section{HUMUS PRODUCTION}

TABLE VI

Humus, per cent Total $\mathrm{CO}_{2}=\mathrm{Cg}$.

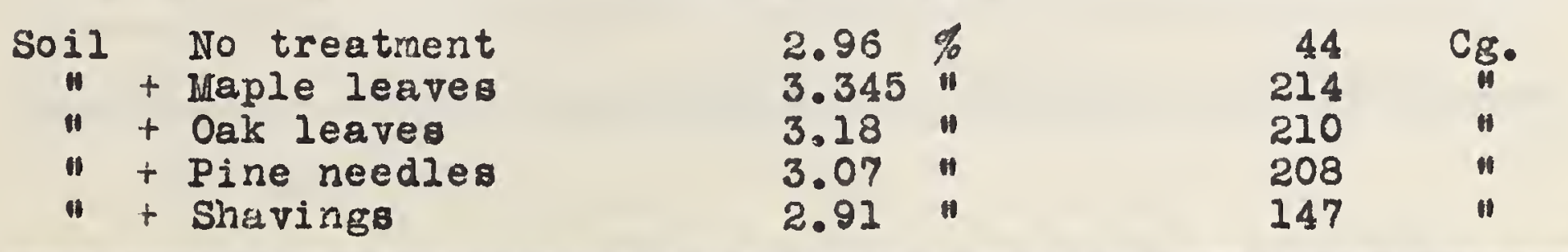

The rate of oxidation, as measured by humus production and $\mathrm{CO}_{2}$ production, follow the same order; namely, (1) maple leaves, (2) oak leaves, (3) pine needles, (4) pine shavings. It should be noted that the shavinge after having been in the so11 for three or four montho did not increase the per cent of humus, in fact, lowered it olightly.

\section{EXPIRIMENT IV}

\section{CERTALS AND BUCKWHAT}

Barley, oats and buckwheat were used because good samples of them were available. Barley and buckwheat are quite 

frequently plowed under as green manure crops, which is not true of oats. Plants that were half matured were dried, ground and mixed with the moist loam. The rate of oxidation was as follows:

TABIE VII MITII GRAMS $\mathrm{CO}_{2}$ PRODUCED

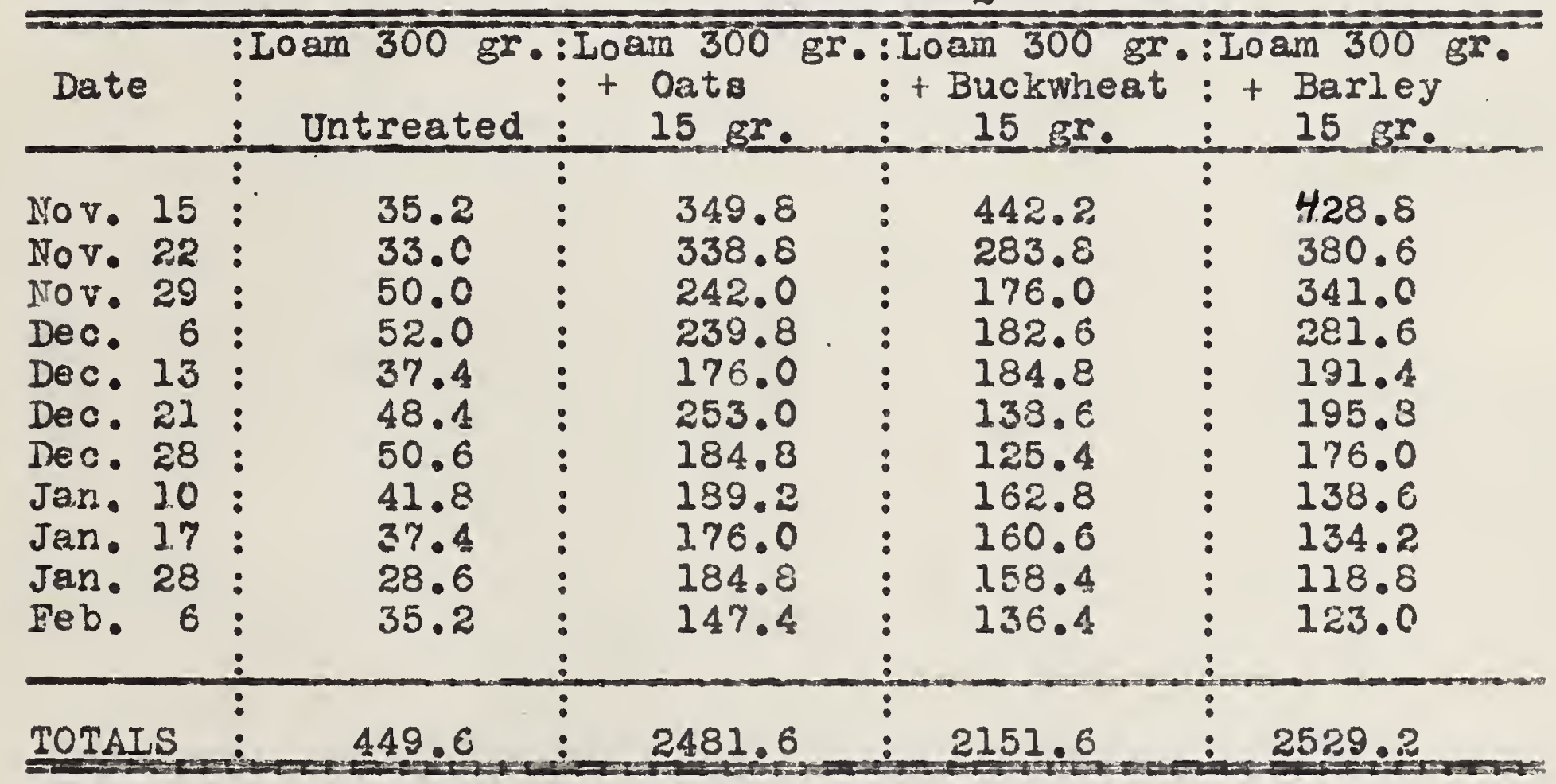

See chart IV

Little or no consiatent variation occurs. Buckwheat appears to be the most inert.

HUIUUS PRODUCTION

TABIE VIII

Humus, per cent Total $\mathrm{CO}_{2}-\mathrm{Cg}$.

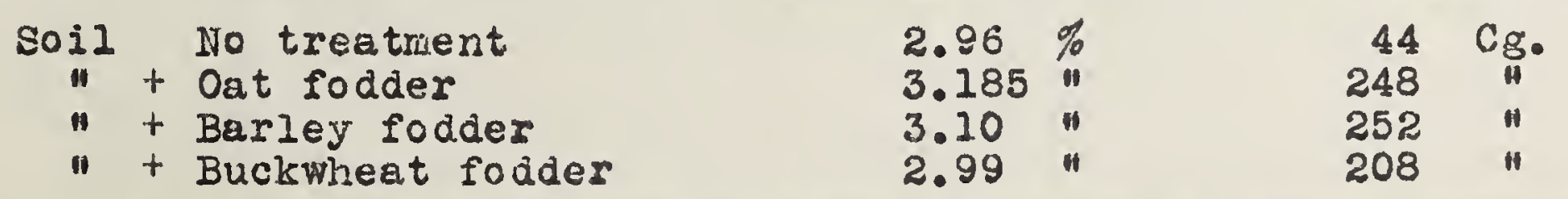

Oats and barley are very nearly the same, the variation being within the limits of error. Buckwheat seems to be a very inert oubstance, increasing the per cent of humus almost 


nil. while the total $\mathrm{CO}_{2}$ given off in three months is considerably lower than the other materials.

\section{GENERAL OBSERVATIONS}

Before the experiment was started it was expected that a wide variation in the rate of decomposition would be shown. Woliney(44) otates tirat: "Legume otrawscontaining a high nitrogen content are easily decomposed, grain straws are more resistant, while leaves and needles are still more so." The results how this to be true, but the difference is not as marked as might be expected. That white pine shavingo should increase the $\mathrm{CO}_{2}$ production as much as they did is peculiar, so it seems that the increased aeration afforded by the 100 ge material has had some effect in causing a greater recovery of $\mathrm{CO}_{2}$.

It should be remerabered that all substances were dried before using, which may account for the uniformity of the results, although Lemmerman (45) founa no difference between green and dry lucern. It would be nearly impossible to obtain, at the ame time, all of the materials at the proper atage of growth ano normal moisture content. To place everything on the same basis it seemed advibable to dry each in the same degree.

For the sake of comparison the humus production of all the materials is given on Chart $V$. It is believed that the Be reaults fairly represent the availability of the substances used. (44) Wollney, Die Zerzetzung der Organischen Stoffe, .1. 405 (45) Lemmerman, 10c. cit. 

Swedes

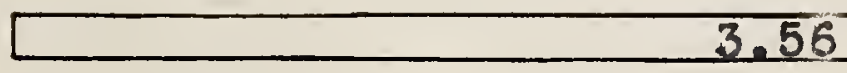

Alfalfa

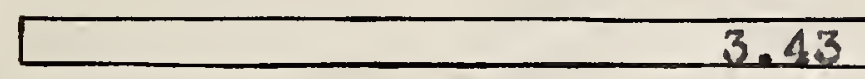

Maple Leaves

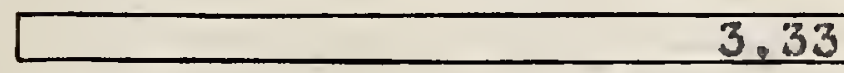

Red Clover

3.29

Soy Beano

3.285

Sugar Beets

3.28

Repe

3.84

Oats

3.285

Oak Leavor

3.38

Barley

3.10

Pine Needjes

3.075

Buckwheat

2.99

Shavings

2.92

Check

$$
2.97
$$

HUMUSS PRODUCTION 



\section{ACPION OF FERTIIIZERS ON DECOIAPOSITION}

A second series of experiments was run along the same period as those just cited in an effort to determine whether or not fertilizer materials increased the rate of decomposition. The same form of apparatus was used.

Fifteen gram of soy bean fodder and one gram of the fertilizer to be tried out were added to each flask.

The results follow:

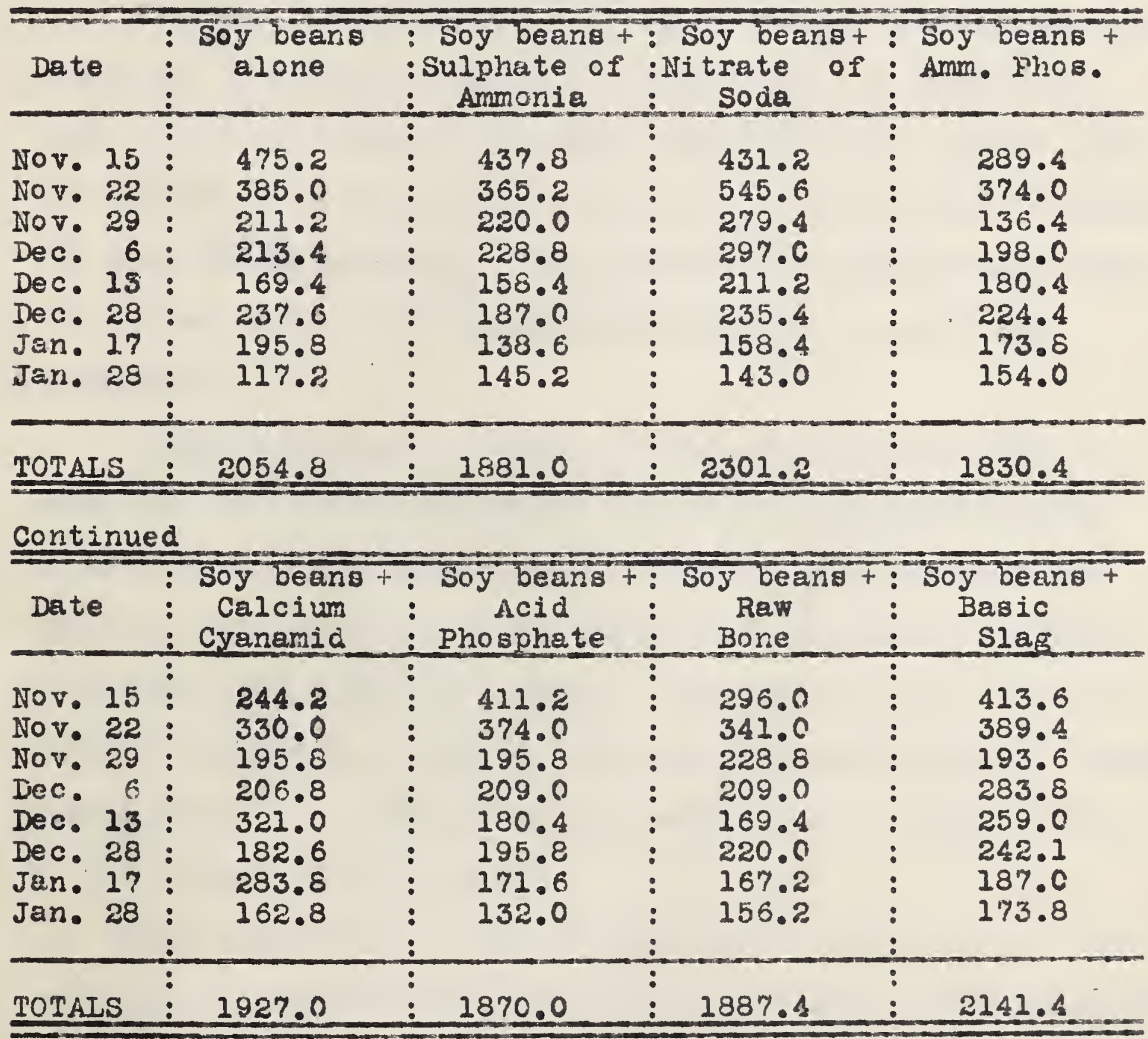





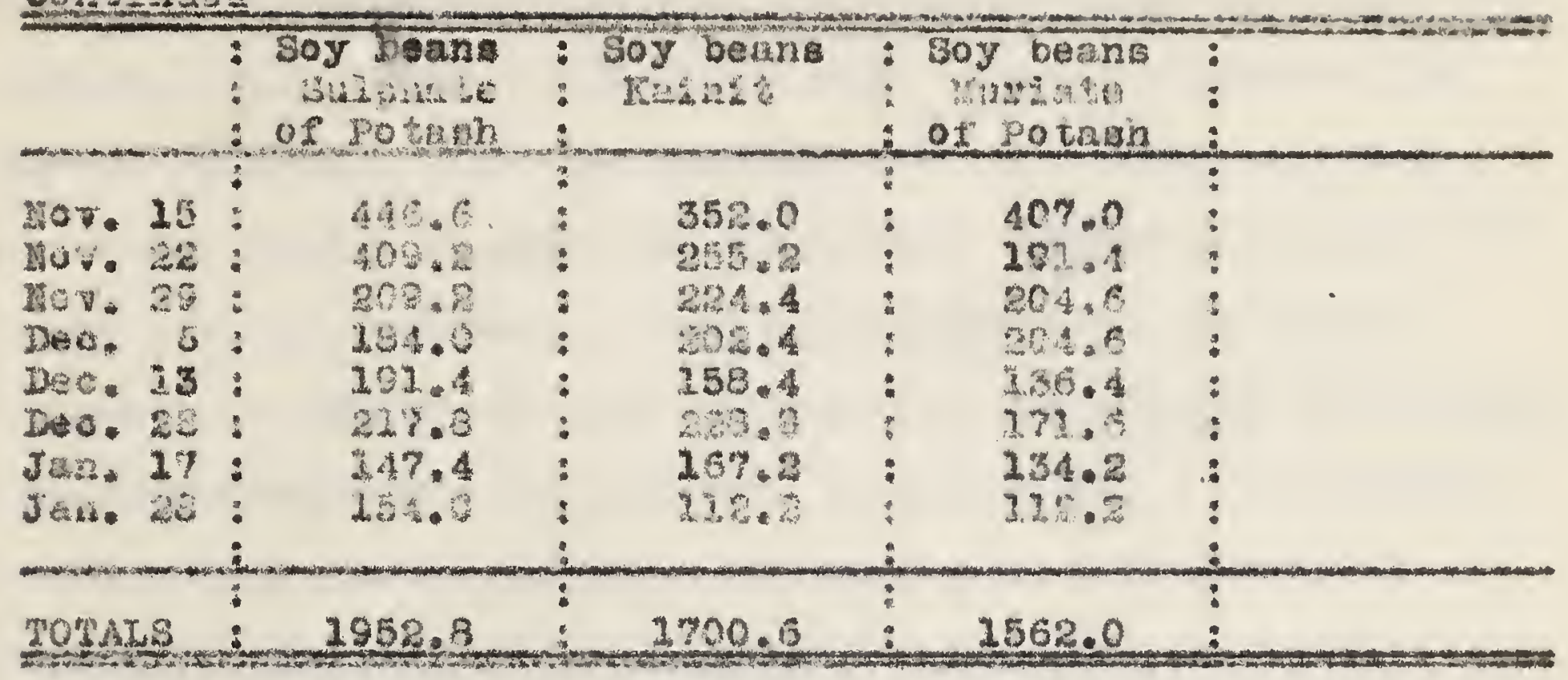

The resulto whow thet but wwo os the fertilizer materiala tribd out increase the rate be decay they axe natrate of

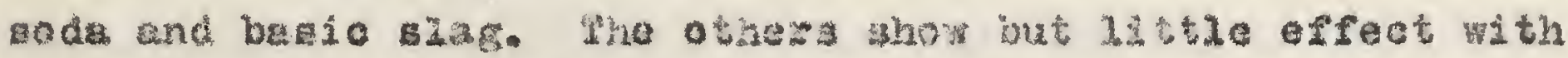

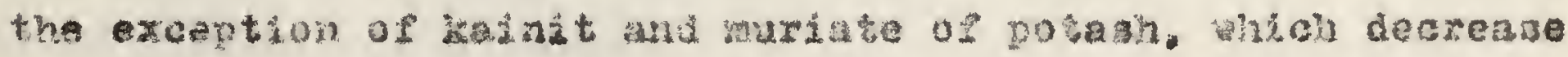

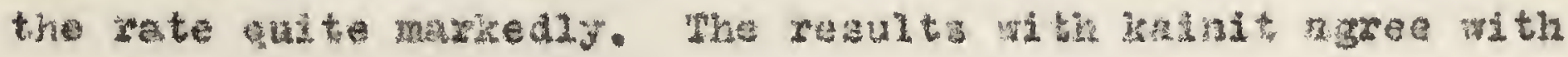

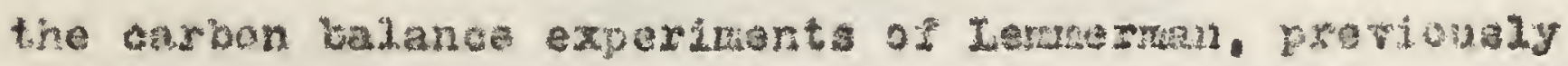
mertioné.

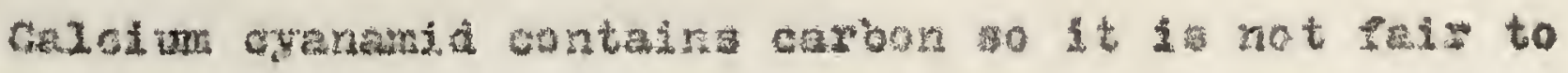

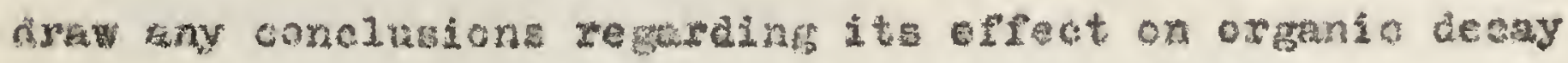
as meatred by cop production. How vex. it apraxe to be

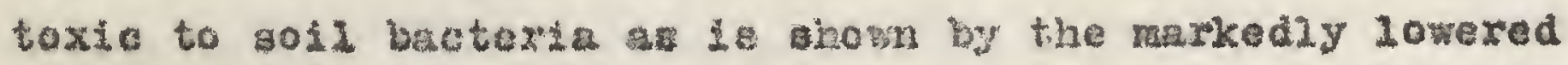

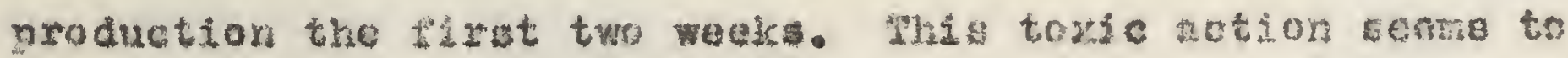

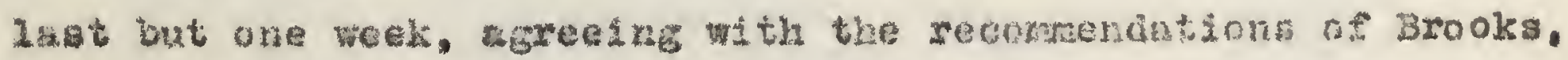

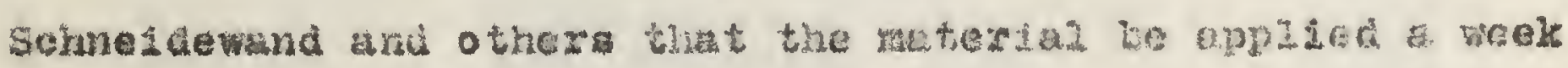

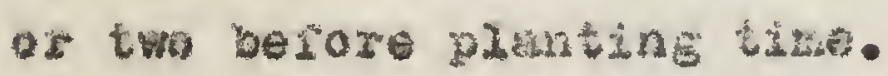

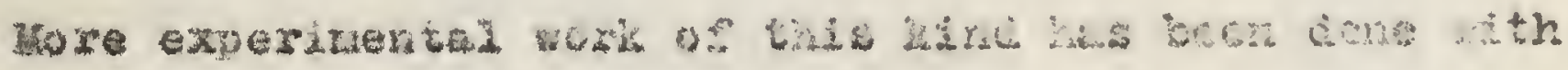

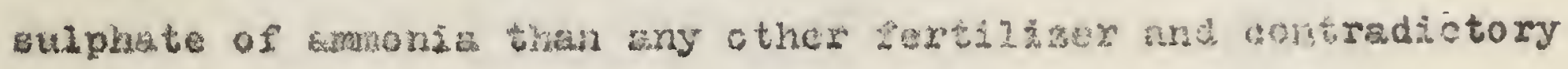

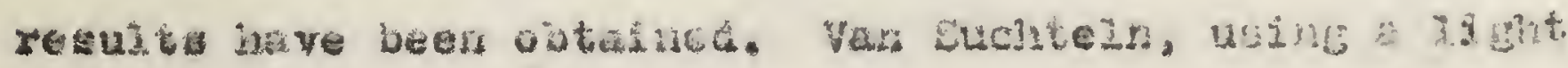
application of sulphate of ammonde and reatering the $\mathrm{CO}_{2}$ for 

a very short period ( 22 hours), obtained much more gas from the treated soil. Fred and Hart(46) made deterninations at two day periods and, while an increase over the check is shown, it is not nearly as great as the above. Potter and snyder(47) found a sight decrease in $\mathrm{CO}_{2}$ production from the use of sulphate of ammonia af did the writer. The results of the last two experimenta are not entirely contradictory to the forner, for the time factor enters. It seems that the immediate effect of the salt is to increase or stimulate bacterial action, hut it is not lasting. The results obtained here, as well as those of Potter and snyder, represent a length of time equivalent to a growing season and for that reason should be of more practical value.

\section{EFEECT ON HUMUS CONTEIVT}

The residue from the oxidation experiments were dried and their humus content determined.

The resulta were as follow:

\section{BFFECT OF FERTILIZIRS ON HURTS CONTENT}

Treatment

\begin{tabular}{|c|c|c|c|}
\hline Soy & beans & 15 & $g r$. \\
\hline$N$ & " & "I & " \\
\hline w & 11 & "1 & " \\
\hline$" 1$ & 11 & H & H \\
\hline II & $\|$ & 11 & " \\
\hline " & 11 & 11 & " \\
\hline$" 1$ & .11 & 11 & $n$ \\
\hline " & $\|$ & " & 11 \\
\hline " & 11 & 11 & " \\
\hline " & " & " & ॥ \\
\hline "f & " & " & A \\
\hline
\end{tabular}

Alone

Kainit, $1 \mathrm{gr}$.

Raw ground bone, 1 gr.

Muriate of Potash, I gr.

Sulphate of Armonia, 1 gr.

Acid Phosphate, 1 gr.

Calcium Cyanamid, $1 \mathrm{gr}$.

Sulphate of Potash, I. gr.

Ammo Phos, I gr.

Rock Phosphate, $1 \mathrm{gr}$.

Basic Slag, 1 gr.

Nitrate of Soda, 1 gr.
Per cent humus

$3.285 \%$

$3.225 \%$

3.195 "

$3.180 "$

$3.175 "$

$3.155 "$

3.130 "

$3.035 "$

$3.000 "$

2.990

$2.970 \mathrm{H}$

$2.865 "$

(46) Fred and Hart, 10c. cit.

(47) Potter and Snyder, 10c. cit. 



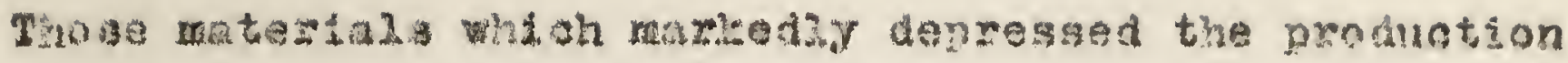

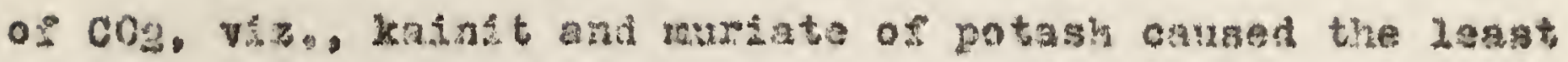

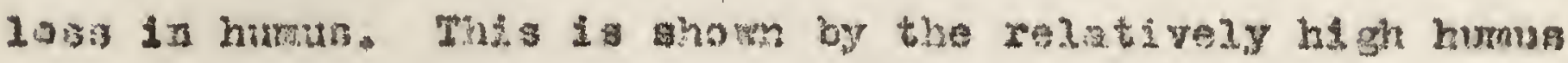

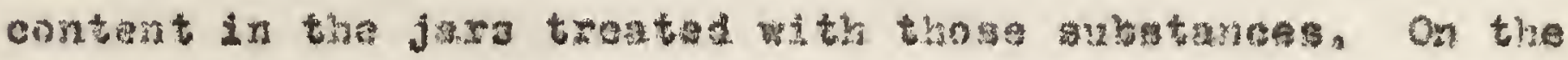
other hand the metatas whol inoreased the production of con, riz,. alas and nitrute of soda, have makediy lowered the kumus content. congidering thit one mat infer that fertilizerg act upon the goll humue and not uoon the crude erganic matter. cre would expect the continued use of materielg ilis nitrate of coda to cause a rapd depletion of the sel1' humue content.

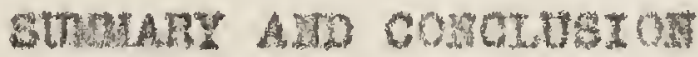

i. The iegume which ere high in nitrogen show a more rapid rete of decaw then strew and 2 ittere which are jow in ntwroger. Wtrogen, then, seems to intuluenoe decomposition.

2. On rama where andmal manures are not avaliable the choice of green manures and cover crops is important. The resulto indicate that lasumes would be nost dealreble on auch fams.

3. Cyanarid appears to be toxic to goil bacteria, or at least arresta the decay of organic matter for two weeks after application.

4. Commercial fertilizers apparently act upon goil humus. decomposing it quite rapidy. Whey apparently do not act upan crude organic matter in the same way. 

